International Journal of Forensic Science \& Pathology (IJFP)

ISSN 2332-287X

\title{
The effect of six common PCR inhibitors on DNA polymerase and DNA template
}

\author{
Research Article
}

Hu Q, Liu Y, Yi S, Huang D*

Department of Forensic Medicine, Tongji Medical College, Huazhong University of Science and Technology, No. 13, Hangkong Road, Wuhan 430030, PR China.

\begin{abstract}
In order to elucidate the effect of PCR inhibitors on DNA polymerase and DNA template, two main components of the PCR reaction, in this paper, we selected six representative PCR inhibitors, bile salts, collagen, humic acid, hemoglobin, melanin and urea, and added respectively them to the K562 DNA with the standard addition concentration in which all of 26 different alleles of the K562 DNA with the AmpF $\ell S T R^{\circledR}$ Identifiler $^{\circledR}$ PCR Amplification Kit are just inhibited completely. On this basis, after increased the amount of K562 DNA and DNA polymerase respectively, PCR amplification and STR genotyping were performed, and then counted the allele number of K562 DNA detected. When the DNA polymerase was increased to a certain amount, all of 26 alleles of the K562 DNA mixed with various PCR inhibitors could be detected successfully, and when the amount of K562 DNA was increased, the inhibitory effect of bile salts, collagen and urea had only been eliminated partly and no significant improvement was observed for the other three inhibitors. The results indicate that all of the six representative PCR inhibitors mainly inhibit DNA polymerase, and increasing the amount of DNA polymerase in PCR reaction can improve significantly the efficiency of PCR amplification and the success rate of genotyping.
\end{abstract}

Keywords: Forensic Science; Biological Sample; DNA Typing; PCR Inhibition

\author{
*Corresponding Author: \\ Daixin Huang, \\ 430030, PR China. \\ Tel: $+86-27-8369-2645$ \\ Fax: +86-27-8363-1216 \\ E-mail: huangdaixin@mails.tjmu.edu.cn
}

Department of Forensic Medicine, Tongji Medical College, Huazhong University of Science and Technology, No. 13, Hangkong Road, Wuhan

Recieved: October 15, 2014

Accepted: November 04, 2014

Published: November 06, 2014

Citation: Hu Q, Liu Y, Yi S, Huang D(2014) The effect of six common PCR inhibitors on DNA polymerase and DNA template. Int J Forensic Sci Pathol, 2(8), 61-64. doi: http://dx.doi.org/10.19070/2332287X-1400017

Copyright: Huang $\mathbf{D}^{\odot}$ 2014. This is an open-access article distributed under the terms of the Creative Commons Attribution License, which permits unrestricted use, distribution and reproduction in any medium, provided the original author and source are credited.

\section{Introduction}

Since it had been invented by Müllis in 1985, PCR technology greatly promoted the development of molecular biology. At present, in the field of forensic science, PCR technology is widely used in DNA analysis of forensic cases. However, biological samples obtained from the crime scenes often contain PCR inhibitors that can interfere with PCR reactions, and this makes forensic DNA testing facing huge challenges. To solve the problem of PCR inhibition, various treatment techniques of inhibitors, such as dilution of the template DNA [1], adding bovine serum albu- min (BSA) [2], magnetic bead capture technology [3] and hot-start PCR [4] had been widely used, which the efficiency of PCR amplification was improved significantly.

Although the effect of PCR inhibitors on the PCR reaction is widely known, the exact mechanism of PCR inhibition remains to be elucidated. Previous studies have shown that PCR inhibitors may have an effect on the various components of the PCR reaction, including DNA polymerase, template DNA, primers, dNTPs and magnesium. A number of possible mechanisms exist to explain PCR inhibition, including inhibition due to the binding of inhibitors to active sites on the thermostable DNA polymerase [57], inhibition due to binding of inhibitors to the DNA template; and inhibition due to loss of the ability of the polymerase to extend the DNA (effects on processivity, interference with dNTPs, etc). Among these, the DNA polymerase and template DNA are two major components that are affected severely [8,9]. For this reason, the aim of this study is to explore the possible inhibition mechanism of six representative PCR inhibitors by studying their effect on the DNA polymerase and template DNA.

\section{Materials and Methods}

\section{Experimental materials}

The K562 DNA with the concentration of $766 \mu \mathrm{g} / \mathrm{mL}$ (Promega, DD2011); bile salt (Sigma, \#B3426); collagen solution (Sigma,\#C8919); hematin (Sigma,\#H3281); humic acid (Sigma, \#53680); melanin (Sigma,\#M8631); urea (Sigma, \#U1250); the AmpF STR $^{\circledR}{ }^{\circledR}$ Identifiler $^{\circledR}$ PCR Amplification Kit (Applied Biosystems, \#4322288); the AmpliTaq Gold ${ }^{\circledR}$ DNA Polymerase with the concentration of $5 \mathrm{U} / \mu \mathrm{L}$ (Applied Biosystems, \#4398823). 


\section{Inhibitor preparation}

The stock solutions of six PCR inhibitors were prepared as follows: bile salt solution with the concentration of $35 \mu \mathrm{g} / \mu \mathrm{L}$ in ultrapure water; collagen solution with the concentration of $1 \mu \mathrm{g} /$ $\mu \mathrm{L}$ in $0.1 \mathrm{M}$ acetic acid; humic acid solution with the concentration of $1.5 \mu \mathrm{g} / \mu \mathrm{L}(15 \mathrm{mg}$ humic acid dissolved in $11.25 \mu \mathrm{L} 1 \mathrm{~N}$ sodium hydroxide, and adding ultrapure water to $10 \mathrm{~mL}$ ); hematin solution with the concentration of $1.99 \mu \mathrm{g} / \mu \mathrm{L}$ (19.9 $\mathrm{mg}$ hematin dissolved in $450 \mu \mathrm{L} 1 \mathrm{~N}$ sodium hydroxide, and adding ultrapure water to $10 \mathrm{~mL}$ ); melanin solution with the concentration of 1 $\mu \mathrm{g} / \mu \mathrm{L}(10 \mathrm{mg}$ melanin dissolved in $100 \mu \mathrm{L} 1 \mathrm{~N}$ sodium hydroxide, and adding ultrapure water to $10 \mathrm{~mL}$ ); urea solution with the concentration of $35 \mu \mathrm{g} / \mu \mathrm{L}$ in ultrapure water.

\section{Determination of the standard addition concentration}

A series of different concentrations of six PCR inhibitor solutions were added to the K562 DNA and ensured the DNA with the concentration of $0.1 \mathrm{ng} / \mu \mathrm{L} .5 \mu \mathrm{L}$ of the DNA solutions mixed with inhibitors was used for PCR amplification in a reaction volume of $25 \mu \mathrm{L}$ with the AmpFeSTR ${ }^{\circledR}$ Identifiler $^{\circledR}$ PCR Amplification Kit. PCR amplifications were performed according to the manufacturer's manual. The amplified products were resolved and detected by capillary electrophoresis using ABI 3130 Genetic Analyzer with denaturing polymer 3130 POP-4TM (Applied Biosystems). Fragment sizing was supported using the Genescan $^{\text {TM}}-500$ LIZ $^{\text {TM }}$ size standards (Applied Biosystems), and the sample run data were analyzed using GeneMapper ID v3.2 software. For the K562 DNA, total of 26 different alleles can be detected in 15 STR loci and the sex-typing marker amelogenin by using the AmpF STR $^{\circledR}$ Identifiler ${ }^{\circledR}$ PCR Amplification Kit. The inhibitor concentration in which all of 26 different alleles of the K562 DNA were just inhibited completely was identified as the standard addition concentration. With this criterion, the standard addition concentrations of six PCR inhibitors were determined as follows: bile salts, $5 \mu \mathrm{g} / \mu \mathrm{L}$; collagen, $220 \mathrm{ng} / \mu \mathrm{L}$; humic acid, 85 $\mathrm{ng} / \mu \mathrm{L}$; hematin, $133 \mathrm{ng} / \mu \mathrm{L}$; melanin $55 \mathrm{ng} / \mu \mathrm{L}$; and urea, 15.3 $\mu \mathrm{g} / \mu \mathrm{L}$.

\section{STR typing for different amount of the K562 DNA mixed with inhibitor}

A series of different concentrations of the K562 DNA solution, including $0.1 \mathrm{ng} / \mu \mathrm{L}, 0.2 \mathrm{ng} / \mu \mathrm{L}, 0.3 \mathrm{ng} / \mu \mathrm{L}, 0.4 \mathrm{ng} / \mu \mathrm{L}, 0.5 \mathrm{ng} /$ $\mu \mathrm{L}, 0.6 \mathrm{ng} / \mu \mathrm{L}, 0.7 \mathrm{ng} / \mu \mathrm{L}, 0.8 \mathrm{ng} / \mu \mathrm{L}, 0.9 \mathrm{ng} / \mu \mathrm{L}$ and $1.0 \mathrm{ng} /$ $\mu \mathrm{L}$, mixed respectively with the standard addition concentration of six inhibitors were prepared. Take $5 \mu \mathrm{L}$ from the 60 prepared DNA solutions respectively as a template for PCR amplification and STR typing according to the above mentioned methods in Determination of the standard addition concentration. All experiments were carried out in triplicate.

\section{STR typing of the K562 DNA mixed with inhibitor using} different amount of DNA polymerase

$5 \mu \mathrm{L}$ of the $\mathrm{K} 562$ DNA solutions $(0.1 \mathrm{ng} / \mu \mathrm{L})$ mixed with the standard addition concentration of six inhibitors respectively were taken as template DNA, and different amount of the AmpliTaq Gold ${ }^{\circledR}$ DNA Polymerase, including $0.5 \mu \mathrm{L}(2.5 \mathrm{U}), 1 \mu \mathrm{L}$ (5.0 U), $1.5 \mu \mathrm{L}$ (7.5 U), $2 \mu \mathrm{L}(10.0 \mathrm{U}), 2.5 \mu \mathrm{L}$ (12.5 U), $3 \mu \mathrm{L}$ (15.0
$\mathrm{U}), 3.5 \mu \mathrm{L}(17.5 \mathrm{U}), 4 \mu \mathrm{L}(20.0 \mathrm{U}), 4.5 \mu \mathrm{L}(22.5 \mathrm{U})$ and $5 \mu \mathrm{L}(25.0$ $\mathrm{U})$, were used for PCR amplification. The condition of PCR amplification and STR typing was the same as the above mentioned methods in Determination of the standard addition concentration. All experiments were carried out in triplicate.

\section{Statistical analysis}

The peak height threshold for allele analysis was set to 50 relative fluorescence units (RFU). The number of different alleles was calculated from the observed genotypes by the gene count method, and taken the average of three repeated experiments as experimental results. The association between different amount of the K562 DNA or DNA polymerase and the average number of STR alleles detected was evaluated using Spearman rank correlation.

\section{Results}

The effect of different amount of template DNA on genotyping of the K562 DNA mixed with inhibitors depended on the the type of inhibitors, and it was significantly different between different inhibitors (Figure. 1). For the inhibition resulted from bile salts, collagen and urea, the improvement was significant $(P$ $<0.01)$ when the amount of the K562 DNA increased from 0.5 $\mathrm{ng}$ to $5 \mathrm{ng}$, and their correlation coefficients were $0.929,0.813$ and 0.700 respectively, which demonstrated a positive correlation between different amount of the K562 DNA and the average number of STR alleles detected. For the inhibition resulted from humic acid, hematin and melanin, however, no significant improvement $(P>0.05)$ had been observed when the amount of the K562 DNA was increased (Figure. 1).

When the amount of the AmpliTaq Gold ${ }^{\circledR}$ DNA Polymerase increased gradually, the number of STR alleles detected from the K562 DNA mixed with the standard addition concentration of various inhibitors also gradually increased (Figure. 2). For all of the six different inhibitors, all of the 26 alleles could be detected when the amount of DNA polymerase reached $15 \mathrm{U}$ (six times the normal amount) (Figure. 2), and all of the improvement was significant $(P<0.01)$.

\section{Discussion}

According to the different sources, PCR inhibitors can be divided into two categories: one is from the biological samples themselves, such as hematin, melanin, and the other is from the reagents used in the extraction and purification process, such as SDS, EDTA, ethanol, excess potassium chloride and sodium chloride [7]. In this paper, all of the selected six representative PCR inhibitors come from the biological samples themselves, and are often encountered in forensic practice, such as hematin in blood; humic acid, an organic component in many soils; collagen, a naturally occurring protein found in bone and connective tissues; urea in urine; melanin in hair [6,10-12].

Because each inhibitor has its own physicochemical characteristics, their inhibition mechanisms to PCR amplification are not the same, and previous studies have shown that some inhibitors such as tannic acid, were more than one way to influence the PCR reaction [13]. In addition, the effect of each inhibitor on the efficiency of PCR amplification was also very different. For example, for the 
Figure 1. The average number of STR alleles detected from different amount of the K562 DNA mixed with inhibitors.

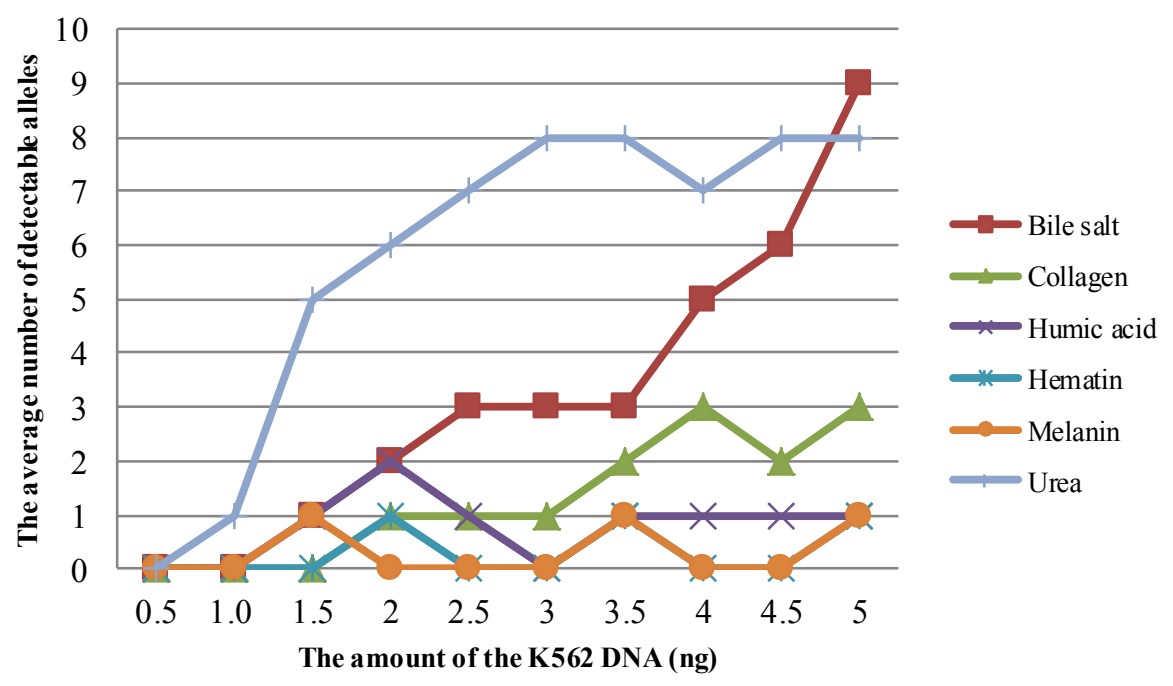

Figure 2. The average number of STR alleles detected from the K562 DNA mixed with inhibitors when different amount of the AmpliTaq Gold ${ }^{\circledR}$ DNA Polymerase were used.

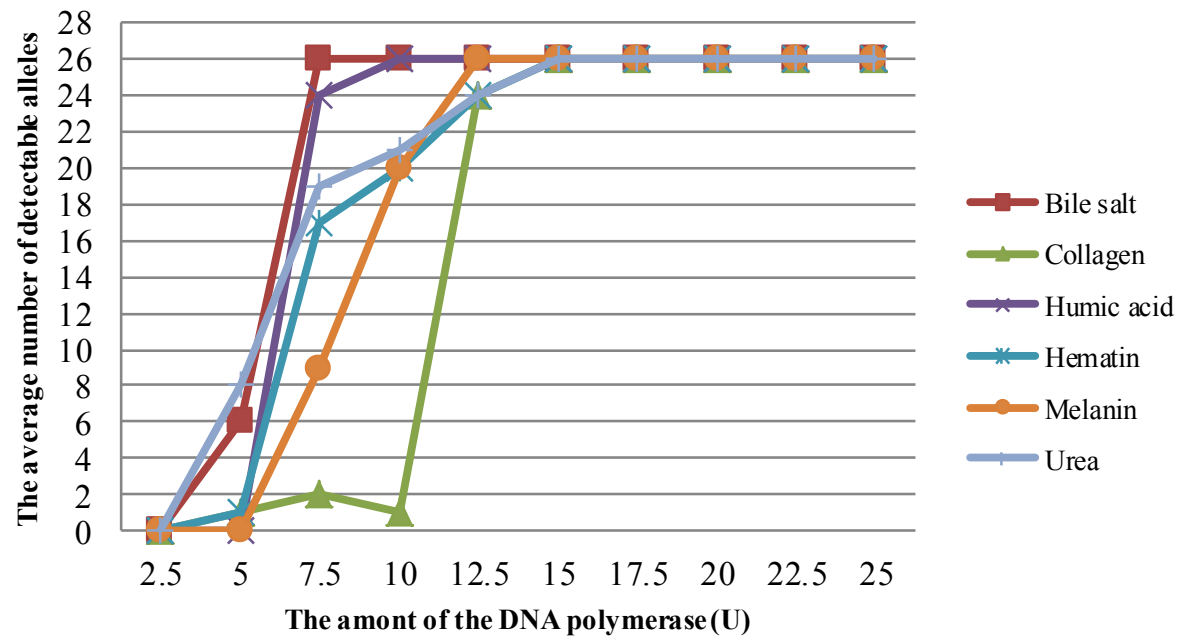

melanin and humic acid, the standard addition concentrations in which all of 26 different alleles of the K562 DNA were just inhibited completely were $55 \mathrm{ng} / \mu \mathrm{L}$ and $85 \mathrm{ng} / \mu \mathrm{L}$ respectively, and were much lower than those of the urea and bile salt.

Some scholars believe that the effect of various inhibitors on PCR reaction focused on the DNA polymerase [14]. However, whether PCR inhibitors only act on the DNA polymerase or act on both the DNA polymerase and template DNA molecules at the same time remains to be elucidated. In this study, the experimental results of increasing the amount of template DNA and DNA polymerase in PCR reaction respectively showed that the issue should be analyzed specifically based on different inhibitors. For example, for the bile salts, collagen and urea, the total number of STR alleles detected from the K562 DNA increased significantly after increasing the amount of DNA polymerase and template DNA in the PCR reaction respectively, which indicated that both inhibitors can act simultaneously on the template DNA molecule and DNA polymerase, and the effect on DNA polymerase was more than on the template DNA molecule. For the other inhibitors, humic acid, hematin and melanin, the PCR reaction had high tolerance to them after increasing the amount of DNA polymerase, while no significant improvement was observed after increasing the amount of template DNA, and this suggested that the three inhibitors inhibited mainly DNA polymerase and had a negligible effect on the template DNA molecule. In addition, as shown in (Figure 2), the required amount of DNA polymerase had obvious difference when all of 26 alleles of the K562 DNA mixed with six inhibitors respectively could be detected, and this also indicated from the other side that the effect of different inhibitors on the DNA polymerase was different.

It should be emphasized that the PCR inhibition mechanism studied in this paper was based on an ideal environment and the experiment was conducted after the K562 DNA was simply mixed with different inhibitors. In forensic practice, however, the biological samples from crime scenes are very complicated, and sometimes may contain two or more different inhibitors. In addition, the structure of some inhibitors such as humic acid is very similar to DNA molecule. Free DNA molecules in soil rapidly adsorb and bind on humic acid especially in acidic environment, and with the extension of adsorption time, humic acid will break double-stranded DNA molecule or encased completely DNA molecules [15-18]. 
In conclusion, although only six representative inhibitors were selected in the study, the results suggest that the increase of the amount of DNA polymerase in PCR reaction can improve significantly the efficiency of PCR amplification and the success rate of genotype of biological samples containing inhibitors.

\section{References}

[1]. A. Alonso, S. Andelinović, P. Martín, D. Sutlović, I. Erceg, et al,(2001) DNA typing from skeletal remains: evaluation of multiplex and megaplex STR systems on DNA isolated from bone and teeth samples, Croat. Med. J. 42: 260-266.

[2]. S. Oikarinen, S. Tauriainen, H. Viskari, O. Simell, M. Knip, et al,(2009) PCR inhibition in stool samples in relation to age of infants, J. Clin. Virol. $44: 211-214$.

[3]. K.K. Yankson, T.R. Steck (2009) Strategy for extracting DNA from clay soil and detecting a specific target sequence via selective enrichment and real-time (quantitative) PCR amplification, Appl. Environ. Microbiol. 75: 6017-6021.

[4]. M.B. Kermekchiev, A. Tzekov, W.M. Barnes (2003) Cold-sensitive mutants of Taq DNA polymerase provide a hot start for PCR, Nucleic Acids Res. 31:6139-6147.

[5]. J. Bickley, J.K. Short, D.G. McDowell, H.C. Parkes (1996) Polymerase chain reaction (PCR) detection of Listeria monocytogenes in diluted milk and reversal of PCR inhibition caused by calcium ions, Lett. Appl. Microbiol. $22: 53-158$.

[6]. L. Eckhart, J. Bach, J. Ban, E. Tschachler (2000) Melanin binds reversibly to thermostable DNA polymerase and inhibits its activity, Biochem. Biophys. Res. Commun. 271: 726-730.

[7]. J. Bessetti (2007) An introduction to PCR inhibitors, Profiles in DNA, 10
:9-10.

[8]. H.A. Powell, C.M. Gooding, S.D. Garrett, B.M. Lund, R.A. Mckee (1994) Proteinase inhibition of the detection of listeria monocytogenes in milk using the polymerase chain reaction, Lett. Appl. Microbiol. 18:59-61.

[9]. P. Saulnier, A. Andremont (1992) Detection of genes in feces by booster polymerase chain reaction, J. Clin. Microbiol. $30: 2080-2083$.

[10]. A. Akane, K. Matsubara, H. Nakamura, S. Takahashi, K. Kimura (1994) Identification of the heme compound copurified with deoxyribonucleic acid (DNA) from bloodstains, a major inhibitor of polymerase chain reaction (PCR) amplification, J. Forensic Sci. $39: 362-372$.

[11]. M. Scholz, I. Giddings, C.M. Pusch (1998) A polymerase chain reaction inhibitor of ancient hard and soft tissue extracts is determined as human collagen type I, Anal. Biochem. 259 :283-286.

[12]. G. Khan, H. O. Kangro, P. J. Coates, R. B. Heath (1991) Inhibitory effects of urine on the polymerase chain reaction for cytomegalovirus DNA, Clin. Pathol. $44: 360-365$.

[13]. K.L. Opel, D. Chung, B.R. McCord (2010) A study of PCR inhibition mechanisms using real time PCR, J. Forensic Sci. 55 :25-33.

[14]. R. Alaeddini (2012) Forensic implications of PCR inhibition - A review, Forensic Sci. Int. Genet. 6:297-305.

[15]. D. Dong, A. Yan, H. Liu, X. Zhang, Y. Xu (2006) Removal of humic substances from soil DNA using aluminium sulfate, J. Microbiol. Methods 66:217-222.

[16]. C. Crecchio, G. Stotzky (1998) Binding of DNA on humic acids: Effect on transformation of Bacillus subtilis and resistance to DNase, Soil Biology and Biochemistry $30: 1061-1067$.

[17]. K. Hiramoto, T. Kato, K. Kikugawa (1993) Generation of DNA-breaking activity in the Maillard reaction of glucose-amino acid mixtures in a solid system, Mutat. Res. $285: 191-198$.

[18]. H.N. Poinar, M. Hofreiter, W.G. Spaulding, P.S. Martin, B.A. Stankiewicz (1998) Molecular coproscopy: dung and diet of the extinct ground sloth Nothrotheriops shastensis, Science 281: 402-406. 